\title{
The Role of Regulatory T cells in Atopic Dermatitis
}

\author{
Rachana Agrawal, PhD1', Julia Wisniewski, MD1, and Judith A. Woodfolk, MBChB, PhD ${ }^{1}$ \\ ${ }^{1}$ Asthma and Allergic Diseases Center, University of Virginia Health System, Charlottesville, VA
}

\section{Abstract}

\begin{abstract}
Regulatory T cells (Tregs) play a pivotal role in immune suppression and are integral to the control of allergic responses. The chronic inflammatory skin condition, atopic dermatitis (AD), is most severe in patients who are sensitized to allergens from diverse sources including foods, pollens, and animal danders, as well as skin-colonizing organisms. These individuals typically present with eczematous skin eruptions in early childhood and evolution of the disease is thought to reflect an underlying dysregulated $\mathrm{T}$ cell response to allergens that manifests as a Th2 response. Studying Tregs in the context of AD from infancy into adulthood could yield insight into their role in disease pathogenesis and reveal new strategies for exploiting these cells for therapeutic purposes. Such studies are challenging in humans owing to the heterogeneous nature of Tregs, lack of a reliable surface marker, and the paucity of knowledge surrounding the emergence of specialized $\mathrm{T}$ cells in early life. Moreover, the blurred distinction between activated effector $\mathrm{T}$ cells and Tregs further complicates studies in the context of inflammatory disorders such as AD. There is emerging evidence to suggest that Tregs can convert to Th2 cells and that this pathway is bi-directional. This phenomenon may be a double-edged sword with important implications not only for subverting Tregs in disease, but also for potential treatments designed to amplify these cells in order to suppress the allergic inflammatory cascade in AD.
\end{abstract}

\begin{abstract}
Atopic dermatitis (AD) is a chronic inflammatory skin condition which can be severe and debilitating. A cellular infiltrate comprising predominantly $\mathrm{T}$ cells is a key feature of $\mathrm{AD}$ skin lesions supporting the view that these cells play a role in disease pathogenesis, and possibly in resolution. As we learn more about the existence of specialized T cell types, the nature of these cells will likely continue to evolve. As is true for many inflammatory disorders, regulatory T cells (Tregs) likely play a pivotal role in AD. Many AD patients are highly allergic and thus, much of what we can glean about Tregs in AD comes from studies on $\mathrm{T}$ cells in the context of allergens and allergic disease. This article provides an overview of key concepts related to Tregs and highlights their relevance to AD.
\end{abstract}

\section{Regulatory T cells in Humans \\ Molecular Signature of Tregs}

There is general consensus that Tregs play an important role in controlling or suppressing $\mathrm{T}$ cell responses to allergens. Human Tregs comprise a highly heterogeneous population as judged by their molecular signature and functional properties [1]. While the characteristics

Corresponding author: Judith A. Woodfolk, MBChB, PhD, Allergy Division, PO Box 801355, University of Virginia Health System, Charlottesville, VA 22908-1355. Tel: 434-924-1293; Fax: 434-924-5779; jaw4m@ virginia.edu.. 
of these cells continues to be the subject of much debate, those most frequently studied express CD25 (IL-2 receptor alpha chain) and the transcription factor Foxp3 (Forkhead/ winged-helix transcription factor box P3). In humans, the levels of CD25 expression appear to correlate with Foxp3 expression. Specifically, CD $25{ }^{\text {hi }} \mathrm{CD} 4{ }^{+}$cells express higher levels of Foxp3, CD25 ${ }^{\text {int }} \mathrm{CD} 4{ }^{+}$cells express lower amounts, and those that are CD25-negative lack Foxp3 expression [1]. Importantly, only those cells that express the highest levels of CD25 (typically comprising $\sim 1-3 \%$ of total $\mathrm{CD} 4^{+} \mathrm{T}$ cells) exhibit suppressive properties.

Verifying human Tregs in health and disease has proven problematic owing to the lack of a distinguishing molecular phenotype. While Foxp3 is a feature of these cells, this molecule can also be induced in resting human effector $\mathrm{T}$ cells $\left(\mathrm{CD} 25^{-} \mathrm{CD} 4^{+}\right)$through $\mathrm{T}$ cell receptor (TCR) activation; however, expression is transient and does not confer suppressive properties [2-4]. Similarly, CD25 is also induced on activated effector T cells. It has recently been suggested that demethylation in the Foxp3 locus provides an improved method for identifying $\mathrm{T}$ cells with suppressor function rather than expression of Foxp3 protein itself $[5,6]$. Other markers which have been used to identify human Tregs include low expression of CD127 (IL-7 receptor alpha chain), expression of LAG-3 (lymphocyte activation gene-3) on activated Tregs, and expression of GITR (Glucocorticoid-induced tumor necrosis factor receptor family-related gene) and CTLA4 (Cytotoxic T lymphocyte-associated antigen 4) [7-10]. However, none of these are exclusive to Tregs.

Preferential expression of several surface molecules has recently been reported on activated human Tregs. One of these, named glycoprotein A repetitions predominant (GARP or LRRC32) is a leucine-rich transmembrane protein. This receptor selectively identifies activated human Foxp $3^{+}$regulatory $\mathrm{T}$ cells $[11,12]$ and regulates Foxp3 gene expression $[13,14]$. Notably, overexpression in human effector cells leads to stable reprogramming towards a regulatory phenotype and function which includes suppression of effector cytokines production, expression of Foxp3, and acquisition of suppressive capacity [13, 15]. By contrast, downregulation of GARP in human Tregs by gene knockdown impairs suppressor function [16]. Other molecules that are expressed on activated Foxp3 ${ }^{+}$Tregs include latency-associated peptide (LAP) and IL-1 receptor type 1 and II (CD121a/CD121b) [17]. However, LAP is also expressed on a novel Treg subset that lacks Foxp3 [18]. Nonetheless, GARP and LAP may prove useful markers for isolating human CD25+Foxp3 ${ }^{+}$ Tregs following expansion ex vivo [19].

\section{Mechanisms of Suppression}

Regulatory $\mathrm{T}$ cells that exhibit the $\mathrm{CD} 25^{\text {hi }}{ }^{\text {Foxp }} 3^{+}$phenotype may represent natural Tregs which constitutively express CD25 upon egress from the thymus. Another type of Tregs, the so-called "adaptive Tregs" are induced by foreign antigens in the periphery. This Treg type includes type 1-like regulatory T cells ( $\operatorname{Tr} 1)$ that secrete IL-10 and suppress antigen-specific responses in a cytokine-dependent manner [1]. In humans, the distinction between natural and adaptive Tregs is unclear and the mechanism of suppression mediated by specific Treg types continues to be debated. There is a broad array of molecules and pathways that have been implicated in suppressive pathways in vitro. The two primary modes include direct suppression of $\mathrm{T}$ cells and suppression through the antigen presenting cell (Figure 1). 
Unfortunately, we still have a lot to learn about the relevance of these in vitro mechanisms to Treg actions in vivo, and how these pathways may be impacted in disease [20, 21]. Pathways implicated in the control or suppression of allergic diseases such as AD include suppression via IL-10 or TGF-beta, as well as contact-dependent mechanisms. Adding to the complex picture, it is increasingly apparent that specialized $\mathrm{T}$ cells, including Tregs, can exhibit plasticity and have the capacity to adapt in an inflammatory milieu [22]. For example, Tregs can "co-opt" transcription factors of the corresponding target effector population in animal models [23, 24]. It has been proposed that this capability may equip Tregs to operate optimally at sites of inflammation.

\section{Regulatory $\mathrm{T}$ cells in Allergic Disease}

Allergic diseases are driven by the development of Th2 cells which mastermind antibody isotype switching to IgE production and an inflammatory cascade involving recruitment and activation of diverse cell types including mast cells, basophils, eosinophils, epithelial cells, dendritic cells and fibroblasts. The Th2 cytokines IL-4, IL-5, IL-9 and IL-13, initiate and perpetuate a chronic cycle of inflammation that results in the manifestation of different types of allergic diseases such as allergic rhinitis, asthma and AD. It is generally accepted that $\mathrm{CD} 25^{+}$Tregs have the capacity to suppress Th2 responses to allergen in vitro. Most experimental systems have used in vitro suppression assays that involve reconstituting $\mathrm{CD} 25^{-}$responder cells with $\mathrm{CD} 25^{+} \mathrm{T}$ cells and monitoring the resulting dose-dependent suppression of proliferation or cytokine responses to allergen. One of the drawbacks of this approach is that $\mathrm{CD} 25^{+} \mathrm{T}$ cells may be contaminated with activated effectors and strategies for isolating $\mathrm{CD} 25^{\text {hi }} \mathrm{T}$ cells are not consistent between studies making these assays difficult to interpret. Moreover, some have argued that the diminished responses observed using this approach do not reflect suppression mediated by Tregs per se, but instead arise from sequestration of IL- 2 by CD $25^{+} \mathrm{T}$ cells. Nevertheless, when considering the substantial body of data collected from allergic and non-allergic subjects, as well as from animal models of allergic disease, a role for Tregs in modulating $\mathrm{T}$ cell responses to allergens is without doubt.

While multiple pathways have been implicated in controlling $\mathrm{T}$ cell responses to allergen, perhaps the most abundant evidence in humans, as well as animal models, supports a role for IL-10. A decrease in the ratio of circulating allergen-specific IL-10- to IL-4-secreting T cells among allergic individuals as compared with healthy non-allergic subjects suggests that alterations in the "balance" between Tregs and Th2 effectors may be a determinant in the development of allergy [25]. Consistent with this notion, a more recent study described decreased CD25 ${ }^{\text {hi }}$ Treg numbers in asthmatic children in both the blood and the respiratory tract, as compared to children with cough or healthy children [26].

Studying T cells obtained from allergic patients during immunotherapy (IT) has yielded important clues regarding the role of Tregs in the induction of protective responses. Since an extensive review of these studies is beyond the scope of this article, we will highlight several key findings. Immunotherapy, which involves administration of incremental doses of allergen through subcutaneous or sublingual routes, has proven clinically efficacious for a variety of allergens including those derived from tree and grass pollens, animal sources, and 
insects. In subjects who are mono-sensitized (ie. sensitized to a single allergen), symptoms are improved for years after stopping treatment [27]. Induction of $\mathrm{CD} 25^{+} \mathrm{Foxp} 3^{+} \mathrm{T}$ cells by IT has been widely reported and while not all studies have verified the functional properties of these cells, those that have generally report suppressive properties. Notably, IL-10 is often implicated in the suppressive mechanism, though other cytokines (TGF- $\beta$ ) and T cellassociated inhibitory signaling molecules (eg. CTLA-4, PD-1) may also be involved [25, 28-31].

Early work linking IL-10 to successful IT in bee venom-allergic patients described increased IL-10 production by $\mathrm{CD} 25^{+} \mathrm{CD} 4{ }^{+} \mathrm{T}$ cells following in vitro activation by the major bee venom allergen, phospholipase A2 (PLA) [32]. This phenomenon was associated with suppressed $\mathrm{T}$ cell proliferation and Th2 cytokine responses to allergen as early as 7 days after initiating treatment. Notably, neutralization of IL-10 fully reconstituted allergeninduced proliferation and cytokine production. In the same study, IL-10 was shown to inhibit PLA-specific and total IgE while enhancing production of IgG4 antibodies. This latter observation suggested that IL-10 not only mediated allergen-specific T cell anergy, but also skewed serum antibody profiles in favor of regulatory isotypes that can inhibit IgEfacilitated allergen presentation [33].

In more recent work on beekeepers exposed to high doses of PLA through natural stings, increases in allergen-specific IL-10-secreting T cells were observed soon after onset of the beekeeping season [31]. This corresponded with a decrease in both IL-4- and IFN- $\gamma$ secreting $\mathrm{T}$ cells which coincided with suppressed in vitro $\mathrm{T}$ cell responses to allergen. Notably, it appeared that in vivo expansion of IL-10-secreting allergen-specific T cells arose from conversion of IL-4-secreting T cells through a mechanism involving histamine binding to the histamine receptor, HR2, on Th2 cells. This supports the view that allergen-specific Th2 cells exhibit functional plasticity. Further elucidation of Tregs induced during IT is warranted in order to better understand their origins and functional properties.

It is not clear what $\mathrm{T}$ cell suppressive mechanisms are involved by administration of allergen using different dosing regimens (eg. conventional IT versus rush IT) and different routes (eg. skin versus sublingual). Nonetheless, it is widely held that the appearance of Tregs during IT reflects the development of allergen tolerance. In addition to their induction by therapeutic administration of allergen, Tregs may also be induced by high dose natural exposure. For example, some individuals who are exposed to high levels of cat allergen in the environment develop a protective immune response that is characterized by the presence of high titer $\operatorname{IgG}$ and $\mathrm{IgG} 4$ antibodies to the major cat allergen, Fel $\mathrm{d}$ 1, in the absence of $\operatorname{IgE}$ antibodies and allergic symptoms [34]. Our group performed T cell epitope mapping studies of Fel d 1 using cultures established from allergic and cat-tolerant individuals in order to analyze T cell mechanisms involved in the development of this "modified Th2" response. Those studies identified a region of the Fel d 1 molecule that preferentially induced IL-10 indicating that this allergen had intrinsic tolerogenic properties [35].

The abundant literature on the biologic properties of allergens highlights the diversity of these molecules and the complex immune pathways that may be triggered by interactions with immune cells. Dendritic cells (DCs) play a key role in driving Th2 responses to 
allergen and this professional antigen presenting cell (APC) is also likely to be critical to the development of Tregs. These cells express an array of surface molecules that may bind allergen and condition DCs to induce specialized T cell subsets. Perhaps the best described is the high affinity IgE receptor, FceRI, which is expressed at increased levels on DCs from highly atopic individuals, including those with AD [36]. Facilitated allergen presentation through this receptor may augment Th2 responses during the effector phase. However, in the initiation phase, generation of Th2 responses likely reflects triggering and convergence of multiple pathways during a critical developmental window in the first years of life. A key role continues to emerge for innate signaling pathways, notably the toll-like receptor 4 (TLR4) pathway, in modulating allergic responses at the T cell level [37]. While much has been written about the ability for the TLR4 ligand, LPS, to dampen Th2 responses, based on its Th1-promoting properties at high dose, less is known about the role of innate signaling pathways in the induction of Tregs. There is evidence in animal models to suggest that TLR pathways are involved in modulating Tregs [38, 39]. However, a variety of different mechanisms have been reported to induce DC-mediated tolerance and these are reviewed elsewhere [40]. When considering allergic disease, it is important to note that the status of the host is also an important factor in determining immune outcome. Recent work by our group suggests that DCs from highly atopic subjects, including those with AD, exhibit intrinsic Th2-promoting properties [41]. Thus, studying these cells in the context of disease could provide new insight into pathways that skew the immune response away from Tregs in favor of Th2 responses.

\section{Regulatory T Cells and Atopic Dermatitis}

In humans, $\mathrm{CD}^{+}$Tregs are present in both the peripheral blood and lymphoid tissues [10, 42-44]. A notable feature of Tregs is that they express a variety of skin-homing addressins including CCR4, CCR6 and cutaneous lymphocyte-associated antigen (CLA) [45-47]. Indeed, it has been suggested that the majority of human Tregs actually reside in the skin where they may play a key role in immune surveillance [48]. While there is no doubt that $\mathrm{T}$ cells infiltrate the inflamed skin of patients with $\mathrm{AD}$, there has been considerable debate surrounding the nature of these cells. Early work reported that Th2 cells are the predominant $\mathrm{T}$ cell type in acute lesions, while those in chronic lesions represented a mixed $\mathrm{T}$ helper profile $[49,50]$. Not surprisingly, increased knowledge of the existence of novel T cell subsets provided the impetus for new observations indicating the presence of a variety of $\mathrm{T}$ cell types, including Th17 cells, in eczematous skin [51]. Despite this, relatively little remains known about recruitment of Tregs to $\mathrm{AD}$ skin, and their function at this site remains enigmatic. IL-10-secreting Tr1 cells can be isolated from lesional AD skin; however, in the same study, CD25 ${ }^{+} \mathrm{Foxp}^{+}$Tregs were absent [52]. By contrast, other work has demonstrated the presence of CD25+Foxp3 " Tregs" at lesional sites [53-55]. Given that activated effector T cells can express Foxp3, further elucidation of these cells is warranted.

Perhaps the most striking evidence of a role for Tregs in protecting against the development of AD comes from the clinical syndrome associated with mutations in the Foxp3 gene. Immune dysregulation, polyendocrinopathy and enteropathy X-linked syndrome (IPEX), is a congenital disorder that is associated with a deficiency in $\mathrm{CD} 25^{+}$Tregs and resulting severe immune dysregulation. IPEX syndrome includes several manifestations that are 
characteristic of allergic disorders including spontaneous development of allergic airway inflammation, hyper IgE, eosinophilia, food allergy and eczema [56-58]. This has led investigators to question whether a decrease in Tregs, or changes in their function, contributes to the pathogenesis of $\mathrm{AD}$.

Studying how Tregs evolve in childhood could yield insight into the development and persistence of AD. Sensitization to food allergens in infancy and beyond may herald onset of the "atopic march" which culminates in sensitization to a broad array of allergens and progression of skin disease [59]. Patients with severe AD are often highly atopic exhibiting sensitization to diverse allergens including inhalants (eg. cat, mite, pollens, etc.) and bacterial sources (eg. skin-colonizing bacteria and fungi). A key question is why some children outgrow their eczema while others do not. Increased CD25+ Tregs have been reported in children who outgrew cow's milk allergy [60]. Moreover, increased numbers of allergen-specific $\mathrm{CD} 25^{+} \mathrm{Foxp} 3^{+}$Tregs were reported in children who developed tolerance to milk and higher Treg numbers correlated with milder clinical symptoms to milk [61]. Collectively, these findings imply that increased Tregs in early life are protective.

In adults with established disease, the $\mathrm{T}$ cell landscape may be more complex. Work by our group revealed an increase in the frequency of circulating CD25 ${ }^{\mathrm{hi}} \mathrm{Foxp}^{+} \mathrm{T}$ cells in patients with $\mathrm{AD}$ as compared with healthy controls and a similar expansion of $\mathrm{CD} 25^{+} \mathrm{Foxp} 3^{+} \mathrm{T}$ cells has been reported by others [45, 62]. These findings contrast with a report of elevated numbers of $\operatorname{Tr} 1$ cells with no variation in $\mathrm{CD} 25^{+} \mathrm{Foxp}^{+} \mathrm{T}$ cells in $\mathrm{AD}$ [54]. While at first glance, expansion of $\mathrm{T}$ cells that co-express CD25 and Foxp3 in AD may seem paradoxical, this may reflect a mixed population comprising activated effector $\mathrm{T}$ cells and Tregs. In order to further elucidate the properties of expanded CD25 $5^{\text {hi }} \mathrm{T}$ cells in $\mathrm{AD}$, we examined expression of additional markers. The results showed that $\mathrm{CD} 25^{\text {hi }}$ Foxp $3^{+} \mathrm{T}$ cells exhibited skin-homing potential based on expression of CLA and CCR4, the receptor for TARC/ CCL17. Notably, TARC is highly expressed in AD skin lesions, and we and others have shown that serum levels of this chemokine correlate with disease severity and IgE titers [6365]. Thus, CCR4 likely plays a pivotal role in recruitment of T cells, including Tregs, to inflamed skin in AD. Despite possessing a molecular signature that comprises a characteristic array of molecules (ie. CD25, CLA, CCR4 and Foxp3), two discrete subtypes of $\mathrm{CD} 25^{\mathrm{hi}} \mathrm{T}$ cells were discernable in $\mathrm{AD}$ patients based on differential expression of the chemokine receptor, CCR6. Specifically, those cells lacking expression of this receptor exhibited Th2-like properties as judged by their cytokine secretion profile upon activation with the bacterial superantigen, staphylococcal enterotoxin B. Moreover, these cells actually amplified secretion of Th2 cytokines when mixed with CD25- effectors [45]. Thus, this novel $\mathrm{CD} 25^{\mathrm{hi}} \mathrm{CCR}^{-}$subtype exhibited Th2-like properties despite bearing the molecular signature of Tregs.

The presence of discrete T cell subtypes within an expanded CD25 $5^{\text {hi }}$ compartment in AD is consistent with the theory of "parallel amplification" whereby expansion of effector T cells is counter-regulated by an expansion of Tregs. Consistent with this viewpoint, recent work using PBMC cultures established from subjects allergic to ryegrass pollen showed that allergen stimulation induced proliferation of both $\mathrm{CD} 25^{+} \mathrm{Foxp} 3^{\text {hi }}$ Tregs and effector $\mathrm{T}$ cells. Interestingly, proliferation of Tregs was decreased in allergic patients and the authors 
concluded that induction of Tregs may be impaired in these subjects, thereby evoking the notion of a Treg deficiency [66].

An important alternate theory to consider is that Tregs are not reduced in numbers in AD, but instead are present, but fail to function in an optimal manner. Impaired Treg-mediated suppression of Th2 cytokine responses to allergen has been observed in pollen allergic subjects, possibly regulated by levels of pollen exposure [67, 68]. Tregs may also be influenced by "pro-allergic" molecules expressed in AD skin. This could include allergens derived from environmental sources or skin-colonizing organisms, as well as a broad array of cytokines. As an example, thymic stromal lymphopoietin (TLSP) is a Th2-promoting cytokine that is expressed by keratinocytes in AD skin lesions. This cytokine mediates its effects primarily at the DC level, but was recently shown to directly and selectively impair IL-10 production by pulmonary Tregs, thereby abrogating their suppressive capacity in patients with asthma [69]. This observation is opposite to the role of TSLP in intra-thymic generation of natural Tregs [70]. Other work supports a role for factors derived from skincolonizing bacteria in altering Treg function. Many patients with AD are colonized with Staphylococcus aureus and IgE antibodies to staphylococcal enterotoxins are common among highly atopic patients [65]. Interestingly, CD25 ${ }^{+}$Tregs fail to suppress proliferation of autologous effector $\mathrm{T}$ cells in response to SEB, but effectively suppress proliferation induced by anti-CD3 [62]. The inhibitory GITR/GITRL pathway has been implicated in SEB-mediated Treg subversion through upregulation of GITR ligand on monocytes [71].

The idea that $\mathrm{T}$ cells may be influenced by the inflammatory milieu is certainly not new. However, it is increasingly apparent that specific $\mathrm{T}$ cell types can exhibit plasticity depending on the microenvironment, and this appears to hold true for Tregs. Notably, attenuation of Foxp3 expression results in conversion of Tregs to Th2 cells and this occurs even in a Th1-polarizing environment $[72,73]$. Moreover, there is evidence to suggest that the conversion pathway is bi-directional. For example, antigen-specific Th2 cells can be redifferentiated into Foxp $3^{+}$Tregs by TGF- $\beta$ in the presence of all-trans retinoic acid and rapamycin [74]. Additionally, Tregs can also convert to other T cell types including Th17 cells. This cell type is induced from naïve T cells by TGF-beta and IL-6. However, Tregs producing TGF-beta can differentiate into Th17 cells in the presence of IL-6 without the requirement for TGF-beta [75]. These aspects of $\mathrm{T}$ cell plasticity may be highly relevant to disease processes in the skin. Numerous studies have demonstrated expression of a broad array of inflammatory factors in AD skin [76]. These include IL-4, IL-5, IL-12, IL-13, IL-17, IFN- $\gamma$, GM-CSF, IL-31, TSLP, and TNF-alpha. Thus, Tregs recruited to inflamed skin are exposed to a host of factors that could influence their ability to function. An intriguing question is whether CD25 $5^{\text {hi }}$ cells that exhibit Th2-like properties in the blood of AD patients constitute Tregs that have undergone conversion [45]. Such a phenomenon could exacerbate the inflammatory cascade in the skin.

\section{Future Directions}

We still have a lot to learn about human Tregs. Further studies on these cells in the context of diseases such as $\mathrm{AD}$ will prove valuable not only for understanding disease processes in the skin, but also for designing new therapies. Identification of new surface markers could 
facilitate improved methods of detection and isolation for functional studies. While there is substantial evidence that Tregs can suppress $\mathrm{T}$ cell responses to allergens, it remains unclear whether $\mathrm{CD} 25^{+}$Tregs in AD are allergen-specific. Techniques using peptide/MHC tetramers to test for $\mathrm{T}$ cell receptor specificity could provide further insight in this regard. Until we learn more about Tregs in AD, it will be difficult to ascertain whether boosting Tregs is an appropriate therapeutic objective. While studies in animal models suggest that Th2 conversion to Tregs is feasible, it is not known whether this approach would translate successfully to humans. An important consideration is whether the Th2-promoting milieu in $\mathrm{AD}$ could hinder or subvert the types of Treg-enhancing strategies used. In contrast to allergic patients without $\mathrm{AD}$, conventional IT can exacerbate skin disease in $\mathrm{AD}$ patients. This may arise from uptake of allergen by skin DCs that have been primed with TSLP [77, 78]. We and others have shown that DCs from AD patients are equipped with the molecular machinery to induce robust Th2 responses [36, 41]. This includes the propensity to efficiently upregulate TSLP receptor upon Fc receptor ligation [41]. Thus, allergen-based treatments that target DCs may not be an appropriate mode for enhancing Tregs in AD. Despite this, there is substantial evidence to suggest that exploiting Tregs could prove a valuable strategy in the armory of treatments for this severe and often debilitating disease.

\section{Acknowledgments}

This work was supported by NIH grants AI-052196 and AI-070364.

\section{References}

1. Shevach EM. From vanilla to 28 flavors: multiple varieties of T regulatory cells. Immunity. 2006; 25:195-201. [PubMed: 16920638]

2. Gavin MA, Torgerson TR, Houston E, DeRoos P, Ho WY, Stray-Pedersen A, et al. Single-cell analysis of normal and FOXP3-mutant human T cells: FOXP3 expression without regulatory T cell development. Proc Natl Acad Sci U S A. 2006; 103:6659-64. [PubMed: 16617117]

3. Pillai V, Ortega SB, Wang CK, Karandikar NJ. Transient regulatory T-cells: a state attained by all activated human T-cells. Clin Immunol. 2007; 123:18-29. [PubMed: 17185041]

4. Allan SE, Crome SQ, Crellin NK, Passerini L, Steiner TS, Bacchetta R, et al. Activation-induced FOXP3 in human T effector cells does not suppress proliferation or cytokine production. Int Immunol. 2007; 19:345-54. [PubMed: 17329235]

5. Baron U, Floess S, Wieczorek G, Baumann K, Grutzkau A, Dong J, et al. DNA demethylation in the human FOXP3 locus discriminates regulatory T cells from activated FOXP3(+) conventional T cells. Eur J Immunol. 2007; 37:2378-89. [PubMed: 17694575]

6. Janson PC, Winerdal ME, Marits P, Thorn M, Ohlsson R, Winqvist O. FOXP3 promoter demethylation reveals the committed Treg population in humans. PLoS One. 2008; 3:e1612. [PubMed: 18286169]

7. Liu W, Putnam AL, Xu-Yu Z, Szot GL, Lee MR, Zhu S, et al. CD127 expression inversely correlates with FoxP3 and suppressive function of human CD4+ T reg cells. J Exp Med. 2006; 203:1701-11. [PubMed: 16818678]

8. Bayry J, Triebel F, Kaveri SV, Tough DF. Human dendritic cells acquire a semimature phenotype and lymph node homing potential through interaction with CD4+CD25+ regulatory T cells. J Immunol. 2007; 178:4184-93. [PubMed: 17371975]

9. Clark RA, Kupper TS. IL-15 and dermal fibroblasts induce proliferation of natural regulatory T cells isolated from human skin. Blood. 2007; 109:194-202. [PubMed: 16968902] 
10. Jonuleit H, Schmitt E, Stassen M, Tuettenberg A, Knop J, Enk AH. Identification and functional characterization of human CD4(+)CD25(+) T cells with regulatory properties isolated from peripheral blood. J Exp Med. 2001; 193:1285-94. [PubMed: 11390435]

11. Wang R, Kozhaya L, Mercer F, Khaitan A, Fujii H, Unutmaz D. Expression of GARP selectively identifies activated human FOXP3+ regulatory T cells. Proc Natl Acad Sci U S A. 2009; 106:13439-44. [PubMed: 19666573]

12. Stockis J, Colau D, Coulie PG, Lucas S. Membrane protein GARP is a receptor for latent TGF-beta on the surface of activated human Treg. Eur J Immunol. 2009; 39:3315-22. [PubMed: 19750484]

13. Probst-Kepper M, Geffers R, Kroger A, Viegas N, Erck C, Hecht HJ, et al. GARP: a key receptor controlling FOXP3 in human regulatory T cells. J Cell Mol Med. 2009; 13:3343-57. [PubMed: 19453521]

14. Wang R, Wan Q, Kozhaya L, Fujii H, Unutmaz D. Identification of a regulatory T cell specific cell surface molecule that mediates suppressive signals and induces Foxp3 expression. PLoS One. 2008; 3:e2705. [PubMed: 18628982]

15. Probst-Kepper M, Balling R, Buer J. FOXP3: required but not sufficient. the role of GARP (LRRC32) as a safeguard of the regulatory phenotype. Curr Mol Med. 2010; 10:533-9. [PubMed: 20642442]

16. Probst-Kepper M, Buer J. FOXP3 and GARP (LRRC32): the master and its minion. Biol Direct. 2010; 5:8. [PubMed: 20137067]

17. Tran DQ, Andersson J, Hardwick D, Bebris L, Illei GG, Shevach EM. Selective expression of latency-associated peptide (LAP) and IL-1 receptor type I/II (CD121a/CD121b) on activated human FOXP3+ regulatory T cells allows for their purification from expansion cultures. Blood. 2009; 113:5125-33. [PubMed: 19299332]

18. Gandhi R, Farez MF, Wang Y, Kozoriz D, Quintana FJ, Weiner HL. Cutting edge: human latencyassociated peptide+ T cells: a novel regulatory T cell subset. J Immunol. 2010; 184:4620-4. [PubMed: 20368276]

19. Tran DQ, Shevach EM. Therapeutic potential of FOXP3(+) regulatory T cells and their interactions with dendritic cells. Hum Immunol. 2009; 70:294-9. [PubMed: 19236900]

20. Shevach EM. Mechanisms of foxp3+ T regulatory cell-mediated suppression. Immunity. 2009; 30:636-45. [PubMed: 19464986]

21. Bettini M, Vignali DA. Regulatory T cells and inhibitory cytokines in autoimmunity. Curr Opin Immunol. 2009; 21:612-8. [PubMed: 19854631]

22. Wan YY. Multi-tasking of helper T cells. Immunology. 2010; 130:166-71. [PubMed: 20557575]

23. Chaudhry A, Rudra D, Treuting P, Samstein RM, Liang Y, Kas A, et al. CD4+ regulatory T cells control TH17 responses in a Stat3-dependent manner. Science. 2009; 326:986-91. [PubMed: 19797626]

24. Zheng Y, Chaudhry A, Kas A, deRoos P, Kim JM, Chu TT, et al. Regulatory T-cell suppressor program co-opts transcription factor IRF4 to control T(H)2 responses. Nature. 2009; 458:351-6. [PubMed: 19182775]

25. Akdis M, Verhagen J, Taylor A, Karamloo F, Karagiannidis C, Crameri R, et al. Immune responses in healthy and allergic individuals are characterized by a fine balance between allergenspecific T regulatory 1 and T helper 2 cells. J Exp Med. 2004; 199:1567-75. [PubMed: 15173208]

26. Hartl D, Koller B, Mehlhorn AT, Reinhardt D, Nicolai T, Schendel DJ, et al. Quantitative and functional impairment of pulmonary CD4+CD25hi regulatory T cells in pediatric asthma. $\mathrm{J}$ Allergy Clin Immunol. 2007; 119:1258-66. [PubMed: 17412402]

27. Durham SR, Walker SM, Varga EM, Jacobson MR, O'Brien F, Noble W, et al. Long-term clinical efficacy of grass-pollen immunotherapy. N Engl J Med. 1999; 341:468-75. [PubMed: 10441602]

28. O'Hehir RE, Gardner LM, de Leon MP, Hales BJ, Biondo M, Douglass JA, et al. House dust mite sublingual immunotherapy: the role for transforming growth factor-beta and functional regulatory T cells. Am J Respir Crit Care Med. 2009; 180:936-47. [PubMed: 19696440]

29. Jutel M, Akdis M, Budak F, Aebischer-Casaulta C, Wrzyszcz M, Blaser K, et al. IL-10 and TGFbeta cooperate in the regulatory $\mathrm{T}$ cell response to mucosal allergens in normal immunity and specific immunotherapy. Eur J Immunol. 2003; 33:1205-14. [PubMed: 12731045] 
30. Francis JN, Till SJ, Durham SR. Induction of IL-10+CD4+CD25+ T cells by grass pollen immunotherapy. J Allergy Clin Immunol. 2003; 111:1255-61. [PubMed: 12789226]

31. Meiler F, Zumkehr J, Klunker S, Ruckert B, Akdis CA, Akdis M. In vivo switch to IL-10-secreting T regulatory cells in high dose allergen exposure. J Exp Med. 2008; 205:2887-98. [PubMed: 19001136]

32. Akdis CA, Blesken T, Akdis M, Wuthrich B, Blaser K. Role of interleukin 10 in specific immunotherapy. J Clin Invest. 1998; 102:98-106. [PubMed: 9649562]

33. Nouri-Aria KT, Wachholz PA, Francis JN, Jacobson MR, Walker SM, Wilcock LK, et al. Grass pollen immunotherapy induces mucosal and peripheral IL-10 responses and blocking IgG activity. J Immunol. 2004; 172:3252-9. [PubMed: 14978133]

34. Platts-Mills T, Vaughan J, Squillace S, Woodfolk J, Sporik R. Sensitisation, asthma, and a modified Th2 response in children exposed to cat allergen: a population-based cross-sectional study. Lancet. 2001; 357:752-6. [PubMed: 11253969]

35. Reefer AJ, Carneiro RM, Custis NJ, Platts-Mills TA, Sung SS, Hammer J, et al. A role for IL-10mediated HLA-DR7-restricted T cell-dependent events in development of the modified Th2 response to cat allergen. J Immunol. 2004; 172:2763-72. [PubMed: 14978075]

36. Novak N, Tepel C, Koch S, Brix K, Bieber T, Kraft S. Evidence for a differential expression of the FcepsilonRIgamma chain in dendritic cells of atopic and nonatopic donors. J Clin Invest. 2003; 111:1047-56. [PubMed: 12671054]

37. Trompette A, Divanovic S, Visintin A, Blanchard C, Hegde RS, Madan R, et al. Allergenicity resulting from functional mimicry of a Toll-like receptor complex protein. Nature. 2009; 457:5858. [PubMed: 19060881]

38. Aumeunier A, Grela F, Ramadan A, Pham Van L, Bardel E, Gomez Alcala A, et al. Systemic Tolllike receptor stimulation suppresses experimental allergic asthma and autoimmune diabetes in NOD mice. PLoS One. 2010; 5:e11484. [PubMed: 20628601]

39. Abdollahi-Roodsaz S, Joosten LA, Koenders MI, Devesa I, Roelofs MF, Radstake TR, et al. Stimulation of TLR2 and TLR4 differentially skews the balance of T cells in a mouse model of arthritis. J Clin Invest. 2008; 118:205-16. [PubMed: 18060042]

40. Pulendran B, Tang H, Manicassamy S. Programming dendritic cells to induce $\mathrm{T}(\mathrm{H}) 2$ and tolerogenic responses. Nat Immunol. 2010; 11:647-55. [PubMed: 20644570]

41. Hulse KE, Reefer AJ, Engelhard VH, Patrie JT, Ziegler SF, Chapman MD, et al. Targeting allergen to FcgammaRI reveals a novel $\mathrm{T}(\mathrm{H}) 2$ regulatory pathway linked to thymic stromal lymphopoietin receptor. J Allergy Clin Immunol. 2010; 125:247-56. e1-8. [PubMed: 20109752]

42. Ng WF, Duggan PJ, Ponchel F, Matarese G, Lombardi G, Edwards AD, et al. Human CD4(+)CD25(+) cells: a naturally occurring population of regulatory T cells. Blood. 2001; 98:2736-44. [PubMed: 11675346]

43. Dieckmann D, Plottner H, Berchtold S, Berger T, Schuler G. Ex vivo isolation and characterization of CD4(+)CD25(+) T cells with regulatory properties from human blood. J Exp Med. 2001; 193:1303-10. [PubMed: 11390437]

44. Levings MK, Sangregorio R, Roncarolo MG. Human cd25(+)cd4(+) t regulatory cells suppress naive and memory $\mathrm{T}$ cell proliferation and can be expanded in vitro without loss of function. J Exp Med. 2001; 193:1295-302. [PubMed: 11390436]

45. Reefer AJ, Satinover SM, Solga MD, Lannigan JA, Nguyen JT, Wilson BB, et al. Analysis of CD25hiCD4+ "regulatory" T-cell subtypes in atopic dermatitis reveals a novel T(H)2-like population. J Allergy Clin Immunol. 2008; 121:415-22. e3. [PubMed: 18177697]

46. Clark RA, Chong B, Mirchandani N, Brinster NK, Yamanaka K, Dowgiert RK, et al. The vast majority of CLA+ T cells are resident in normal skin. J Immunol. 2006; 176:4431-9. [PubMed: 16547281]

47. Hirahara K, Liu L, Clark RA, Yamanaka K, Fuhlbrigge RC, Kupper TS. The majority of human peripheral blood CD4+CD25highFoxp3+ regulatory $\mathrm{T}$ cells bear functional skin-homing receptors. J Immunol. 2006; 177:4488-94. [PubMed: 16982885]

48. Kupper TS, Fuhlbrigge RC. Immune surveillance in the skin: mechanisms and clinical consequences. Nat Rev Immunol. 2004; 4:211-22. [PubMed: 15039758] 
49. Thepen T, Langeveld-Wildschut EG, Bihari IC, van Wichen DF, van Reijsen FC, Mudde GC, et al. Biphasic response against aeroallergen in atopic dermatitis showing a switch from an initial TH2 response to a TH1 response in situ: an immunocytochemical study. J Allergy Clin Immunol. 1996; 97:828-37. [PubMed: 8613640]

50. Grewe M, Bruijnzeel-Koomen CA, Schopf E, Thepen T, Langeveld-Wildschut AG, Ruzicka T, et al. A role for Th1 and Th2 cells in the immunopathogenesis of atopic dermatitis. Immunol Today. 1998; 19:359-61. [PubMed: 9709503]

51. Eyerich K, Pennino D, Scarponi C, Foerster S, Nasorri F, Behrendt H, et al. IL-17 in atopic eczema: linking allergen-specific adaptive and microbial-triggered innate immune response. J Allergy Clin Immunol. 2009; 123:59-66. e4. [PubMed: 19056110]

52. Verhagen J, Akdis M, Traidl-Hoffmann C, Schmid-Grendelmeier P, Hijnen D, Knol EF, et al. Absence of T-regulatory cell expression and function in atopic dermatitis skin. J Allergy Clin Immunol. 2006; 117:176-83. [PubMed: 16387603]

53. Caproni M, Antiga E, Torchia D, Volpi W, Barletta E, Gitti G, et al. FoxP3-expressing T regulatory cells in atopic dermatitis lesions. Allergy Asthma Proc. 2007; 28:525-8. [PubMed: 18034969]

54. Szegedi A, Barath S, Nagy G, Szodoray P, Gal M, Sipka S, et al. Regulatory T cells in atopic dermatitis: epidermal dendritic cell clusters may contribute to their local expansion. Br J Dermatol. 2009; 160:984-93. [PubMed: 19222459]

55. Fujimura T, Okuyama R, Ito Y, Aiba S. Profiles of Foxp3+ regulatory T cells in eczematous dermatitis, psoriasis vulgaris and mycosis fungoides. Br J Dermatol. 2008; 158:1256-63. [PubMed: 18363755]

56. Bennett CL, Christie J, Ramsdell F, Brunkow ME, Ferguson PJ, Whitesell L, et al. The immune dysregulation, polyendocrinopathy, enteropathy, X-linked syndrome (IPEX) is caused by mutations of FOXP3. Nat Genet. 2001; 27:20-1. [PubMed: 11137993]

57. Chatila TA, Blaeser F, Ho N, Lederman HM, Voulgaropoulos C, Helms C, et al. JM2, encoding a fork head-related protein, is mutated in X-linked autoimmunity-allergic disregulation syndrome. $\mathrm{J}$ Clin Invest. 2000; 106:R75-81. [PubMed: 11120765]

58. Wildin RS, Ramsdell F, Peake J, Faravelli F, Casanova JL, Buist N, et al. X-linked neonatal diabetes mellitus, enteropathy and endocrinopathy syndrome is the human equivalent of mouse scurfy. Nat Genet. 2001; 27:18-20. [PubMed: 11137992]

59. Ker J, Hartert TV. The atopic march: what's the evidence? Ann Allergy Asthma Immunol. 2009; 103:282-9. [PubMed: 19852191]

60. Karlsson MR, Rugtveit J, Brandtzaeg P. Allergen-responsive CD4+CD25+ regulatory T cells in children who have outgrown cow's milk allergy. J Exp Med. 2004; 199:1679-88. [PubMed: 15197226]

61. Shreffler WG, Wanich N, Moloney M, Nowak-Wegrzyn A, Sampson HA. Association of allergenspecific regulatory $\mathrm{T}$ cells with the onset of clinical tolerance to milk protein. J Allergy Clin Immunol. 2009; 123:43-52. e7. [PubMed: 19130927]

62. Ou LS, Goleva E, Hall C, Leung DY. T regulatory cells in atopic dermatitis and subversion of their activity by superantigens. J Allergy Clin Immunol. 2004; 113:756-63. [PubMed: 15100684]

63. Vestergaard C, Bang K, Gesser B, Yoneyama H, Matsushima K, Larsen CG. A Th2 chemokine, TARC, produced by keratinocytes may recruit CLA+CCR4+ lymphocytes into lesional atopic dermatitis skin. J Invest Dermatol. 2000; 115:640-6. [PubMed: 10998136]

64. Kakinuma T, Nakamura K, Wakugawa M, Mitsui H, Tada Y, Saeki H, et al. Thymus and activation-regulated chemokine in atopic dermatitis: Serum thymus and activation-regulated chemokine level is closely related with disease activity. J Allergy Clin Immunol. 2001; 107:53541. [PubMed: 11240957]

65. Reefer AJ, Satinover SM, Wilson BB, Woodfolk JA. The relevance of microbial allergens to the IgE antibody repertoire in atopic and nonatopic eczema. J Allergy Clin Immunol. 2007; 120:15663. [PubMed: 17507082]

66. Mittag D, Scholzen A, Varese N, Baxter L, Paukovics G, Harrison LC, et al. The effector T cell response to ryegrass pollen is counterregulated by simultaneous induction of regulatory T cells. $\mathrm{J}$ Immunol. 2010; 184:4708-16. [PubMed: 20308632] 
67. Grindebacke H, Wing K, Andersson AC, Suri-Payer E, Rak S, Rudin A. Defective suppression of Th2 cytokines by CD4CD25 regulatory T cells in birch allergics during birch pollen season. Clin Exp Allergy. 2004; 34:1364-72. [PubMed: 15347368]

68. Ling EM, Smith T, Nguyen XD, Pridgeon C, Dallman M, Arbery J, et al. Relation of CD4+CD25+ regulatory T-cell suppression of allergen-driven T-cell activation to atopic status and expression of allergic disease. Lancet. 2004; 363:608-15. [PubMed: 14987885]

69. Nguyen KD, Vanichsarn C, Nadeau KC. TSLP directly impairs pulmonary Treg function: association with aberrant tolerogenic immunity in asthmatic airway. Allergy Asthma Clin Immunol. 2010; 6:4. [PubMed: 20230634]

70. Watanabe N, Wang YH, Lee HK, Ito T, Cao W, Liu YJ. Hassall's corpuscles instruct dendritic cells to induce CD4+CD25+ regulatory T cells in human thymus. Nature. 2005; 436:1181-5. [PubMed: 16121185]

71. Cardona ID, Goleva E, Ou LS, Leung DY. Staphylococcal enterotoxin B inhibits regulatory T cells by inducing glucocorticoid-induced TNF receptor-related protein ligand on monocytes. J Allergy Clin Immunol. 2006; 117:688-95. [PubMed: 16522472]

72. Wan YY, Flavell RA. Regulatory T-cell functions are subverted and converted owing to attenuated Foxp3 expression. Nature. 2007; 445:766-70. [PubMed: 17220876]

73. Joetham A, Matsubara S, Okamoto M, Takeda K, Miyahara N, Dakhama A, et al. Plasticity of regulatory T cells: subversion of suppressive function and conversion to enhancement of lung allergic responses. J Immunol. 2008; 180:7117-24. [PubMed: 18490710]

74. Kim BS, Kim IK, Park YJ, Kim YS, Kim YJ, Chang WS, et al. Conversion of Th2 memory cells into Foxp3+ regulatory T cells suppressing Th2-mediated allergic asthma. Proc Natl Acad Sci U S A. 2010; 107:8742-7. [PubMed: 20421479]

75. Xu L, Kitani A, Fuss I, Strober W. Cutting edge: regulatory T cells induce CD4+CD25-Foxp3- T cells or are self-induced to become Th17 cells in the absence of exogenous TGF-beta. J Immunol. 2007; 178:6725-9. [PubMed: 17513718]

76. Oyoshi MK, He R, Kumar L, Yoon J, Geha RS. Cellular and molecular mechanisms in atopic dermatitis. Adv Immunol. 2009; 102:135-226. [PubMed: 19477321]

77. Soumelis V, Reche PA, Kanzler H, Yuan W, Edward G, Homey B, et al. Human epithelial cells trigger dendritic cell mediated allergic inflammation by producing TSLP. Nat Immunol. 2002; 3:673-80. [PubMed: 12055625]

78. Ito T, Wang YH, Duramad O, Hori T, Delespesse GJ, Watanabe N, et al. TSLP-activated dendritic cells induce an inflammatory T helper type 2 cell response through OX40 ligand. J Exp Med. 2005; 202:1213-23. [PubMed: 16275760] 
Direct suppression of T cells

- IL-10, TGF- $\beta$, IL-35

- IL-2 consumption

- Galectin-1

- Cytolysis

Suppression of APC

- CTLA-4/CD80 or CD86

- LAG-3/MHCII

- CD39/AMP

- Nrp-1

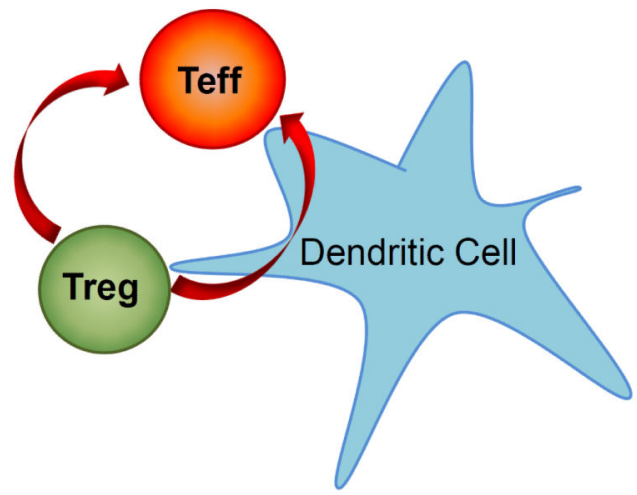

Additional molecules \& mechanisms

- LAP, GARP

- Co-opting $\mathrm{T}_{\text {eff }}$ transcription factors: IRF-4 (Th2) STAT-3 (Th17)

Figure 1.

Molecules and mechanisms implicated in suppression mediated by human regulatory $\mathrm{T}$ cells. 


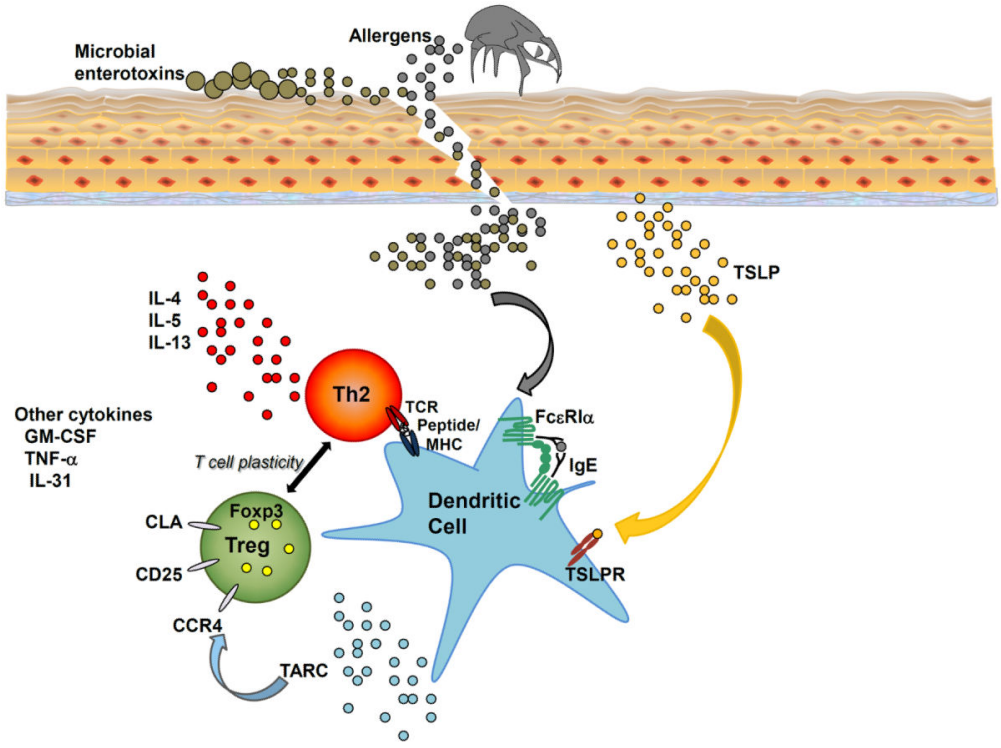

Figure 2.

Schematic depicting the "pro-inflammatory milieu" in AD skin lesions that may influence T cell function at this site. 